\title{
GEOLOGICAL SURVEYS IN S.E. ASIA.
}

SIR,-I have just received a copy of Methods in Geological Surveying by Dr. Edward Greenly and Dr. Howell Williams. On pp. 103-18 the authors give a list of countries with geological surveys, but no mention is made of the Federated Malay States or Malaya. The completed geological map of Malaya was published by the Survey Department last year. In 1926 a "Progress Map" was published. A geological map of Kinta was published in 1927. Other maps of South Perak, Selangor, Negri Sembilan, and Ulu Pahang have been published.

On p. 119, paragraph 7 , the authors state that practically the whole of the East Indian Archipelago is untouched as far as geological surveying is concerned. This shows that the authors have ignored the work of Dutch geologists in the Netherlands East Indies as completely as they have ignored that of my Department. One of the finest geological maps ever produced is that of Java and Madoera, by Verbeek and Fennema, published in 1896. This is in twenty-six sheets on the scale 1:200,000. The Netherlands Indies Geological Survey is now publishing a Geological Atlas of the whole of the Dutch East Indies, sheet by sheet. Their Folio 11 (eleven) contains the Malay Peninsula, and I was invited to supply a geological map of the Peninsula up-to-date. This was publishea in 1925 on the scale $1: 1,000,000$. I have in my office two sheets of their Atlas joined together, that containing the Malay Peninsula and the adjoining sheet containing a large part of Sumatra, the Lingga Archipelago, and Banka. Reference to the "Jaarboek van het Mijnwezen" will show that many other geological maps of parts of the Dutch East Indies have been published. The authors' statement that practically the whole of extra-Indian continental Asia is untouched will also interest the French geologists who are working in Indo-China. In 1929 Monsieur F. Blondel, then Director of their survey, suggested at the Fourth Pacific Science Congress that geologists should co-operate in producing a small-scale geological map of countries in Asia near the Pacific Ocean. It was agreed that British Malaya, the Netherlands Indies, and French Indo-China could produce such a map, but that as Siam has no geological survey, Indo-China and Malaya cannot yet "join up".

J. B. SCRIVENOR,

Director, Geological Survey, Federated Malay States.

\footnotetext{
Geological Survey Department,

Bate Gajah,

Federated Malay States. 24 th February, 1931.
} 